\title{
Analysis on the Reform and Development of Higher Education and Its International Experience
}

\author{
Lina Zhuang ${ }^{1, a}$ \\ ${ }^{1}$ Institute for Developmental and Strategic Studies of Higher Education, Changchun University of \\ Science and Technology, Changchun, Jilin, 130022 \\ ${ }^{a}$ email
}

Keywords: Higher Education, International Experience, Reform and Development

\begin{abstract}
As Chinese socio-economic and political system is gradually changing, our higher education is constantly reforming in higher education reform. It is difficult to produce inevitable. Reform of higher education has become the key to academic research. Meanwhile, Chinese development of transnational higher education, capacity building is the core issue of quality problems. Only high-quality cross-border higher education, can promote capacity building of higher education and develop quality standards, countries need human resources and ultimately improve the country's competitiveness in the international area.
\end{abstract}

\section{Introduction}

Higher Education Management Plan refers to central or local governments, and colleges of education in accordance with national policies and laws, regulations, policies, to achieve the training objectives and aspects of higher education carried out, organizing, directing, coordinating, supervising and control a there is a continuous series of events purpose. It includes the macro-management of higher education (education administration) and micro-management of higher education (Colleges Internal Management) of two parts. Traditionally, the macro-management of higher education refers to the state administrative department of education according to the law of development of higher education and the purpose of the national higher education and there are plans to coordinate the various relationships and resources of the entire higher education system, to ensure the country to cultivate high-level personnel to achieve the objective process. Solve the problem of the relationship between the government administrative departments of education and universities. This article explores the Management System of Higher Education from the macro aspects of.

\section{Situation of Higher Education in China}

Although Chinese current management system of higher education with the development of market economy formation of a "centralized leadership and decentralized management" model, but in the actual management still has significant difficulty coordinating centralized leadership and decentralized administration decentralization difficult characteristics. This management is not only embodied between the central and local governments, government and universities, but also in conflict with the WTO relevant provisions on education services. Higher management activities to varying degrees from top to bottom appeared offside management, the absence of policies and regulations, implementation of the system is not in place.

From the current management system of higher education, the central authority has the largest higher education management and decision-making functions of the State Higher Education Management under the jurisdiction of local government agencies and colleges and universities to implement hierarchical management, substantially this management model from nature or not get rid of administrative centralization mode under the planning system, but a change of administrations, schools "dependency" remains unchanged, the entity running the school is not autonomous in nature.

The past two decades, many countries have enacted laws and regulations for the management of 
higher education, but the WTO Trade in Services "common rule" requires a significant absence, many with suitable regulations and even gaps. For example, higher education standards and open services market, a fair, open and fair competition rules, social supervision of higher education, scientific and standardized system of classification assessment, foreigners or foreign institutions on how to enjoy national treatment and financing schools, colleges and universities abroad China preferential policies and measures for the protection of school education to open up foreign markets, non-governmental school funding policy, etc., there is nowhere, no operability or absence of institutional issues. Even promulgated and implemented the "Interim Measures Higher overseas education," "People's Republic of China Sino-foreign Cooperation in Running Schools" and the "People's Republic of China to implement the Joint Education Ordinance approach", but they are some of the principle of provisions and in particular embodiments there are some difficulties.

\section{Management Measures of Deepening the Reform of Higher Education}

In a sense, the current countries of the Higher Education Management System reflects some similarities and globalization of higher education, but I still have according to different social and cultural background to understand the formation of this trend. Because the management system of higher education has a special structure, reflects the deeply rooted in the times, society and local special idea, no two countries had adopted the same system in the form of higher education management. The author attempts to depart from such a position, summarized and analyzed from the perspective of multi-dimensional theoretical foundation of Chinese higher education management decentralization.

When the market plays in higher education increasingly important role when the Government is also developing higher education assume ever greater responsibility. The government should manage higher education, rather than colleges and universities; government turned to the oarsman at the helm, the athlete becomes the referee, and with the improvement of the level of athletes, expanding the game to improve the level and scope of the rules the referee must make appropriate changes and adjustments.

Strong provincial government is coordinating the requirements of regional economic development, but also the central institutional reform and transformation of government functions is the objective needs. Strengthening Provincial Government decision-making in higher education, it is the place with the world development trend of higher education consistent. US state government management experience of higher education is something we learn. I integrated the views of other scholars and we believe that to continue to adhere to the principle of ensuring the country's major political unity under the premise of higher education in the implementation of the zoning principle of guidance. This inter-regional imbalance in economic development of our higher education is concerned, all the more necessary.

Local institutions of higher learning levels of development and strength are not the same, not the same level Moreover, the local government higher education to create a fair competitive environment is an important responsibility of local governments. Coupled with the result of increased international exchanges, foreign students and foreign schools should be in place "settled", so the local government to take equity, fairness and justice policies on them, which is the development and exchange of academic disciplines, traditions and cultural characteristics carry forward, in particular the promotion of regional economic development, improve the international reputation of our country and so on, all have invisible influence.

With the deepening of Chinese reform and opening up, international exchanges and cooperation in higher education is becoming more and more indispensable. Local levels of government should expand the area of higher education outside world, strengthening international exchanges and cooperation in the region's colleges and universities play an important role. Local Government under the guidance of relevant state laws and policies, and can enact local regulations or policies: strengthening regional and local institutions of higher learning to carry out exchange between scholars and students, scientific research cooperation and joint research, joint educational and other international exchanges and cooperation activities; to encourage the region's colleges and 
universities by law independently carry out scientific and cultural exchanges and cooperation with foreign institutions. Thereby, promoting higher education in the region of extensive international exchanges and cooperation activities is undertaken to further promote the internationalization of higher education in the region.

\section{International Experience of Higher Education Reform}

British Open University pioneered distance education precedent, it uses distance learning and open educational forms, combined with modern teaching techniques correspondence, television, radio, computer networks, has a novel way of developing education, complete professional settings, grand scale school. Since its inception it has achieved great success, played an important role in lifelong education. The Open University has degree-granting 180,000 existing registered more than 200,000 students, is the UK's largest university, its teaching quality has reached international standards, and has made significant educational effect. In particular, the quality of teaching has been higher than ordinary engineering Oxford, Cambridge and Imperial College, London. British Open University has become an internationally renowned universities and institutions of adult higher education have distinctive characteristics, promoting its global non-full-time higher education plays a big role. In recent years, the British Open University presents a new trend to study the current situation of reform and development of higher education in the form of the structure has important practical significance.

In recent years, with the increase of the growing size of the school's British Open University and opportunities for international exchanges and cooperation in education, in line with the Open University to make different plans in line with the principles of the different needs of different countries, according to the specific conditions in different countries and regions, the use of cooperation school, relying on schools, contract schools, and other promotional programs running mode to play their own advantages and characteristics. In addition, the Open University teaching program also innovative aspects of the reform, became the first university to provide a modular degree programs allow students to accumulate credits. Currently, the British Open University has more than 30 countries, Singapore, the United States, Canada, and other country to carry out cooperation projects, attracting a large number of overseas students. With the increasing number of overseas students, international experience, more and more British Open University. According to statistics, the British Open University's overseas students currently distributed in 43 countries. If the state will arrange for the examination of overseas students count, involves up to more than 110 countries.

The great development of higher education in the United States reflected in the use of information technology to reform in the form of higher education, to provide convenient and effective higher education. Virtual University is the product of the changing times. Virtual University mainly refers to include built on digital technology, network communication technology, multimedia technology, computer technology and other technical components of modern information technology platform as a teaching model based on the application of computer technology and computer networks. It is founded on the Internet does not consume less resources and energy consumption of real education and practical features and functions of a university educational entity. With the extensive application of information technology in the field of higher education, virtual universities came into being. 1990s, there have been a number of well-known virtual universities. University of Phoenix is America's most successful models. Subsequently, the virtual university most US states came into being.

In recent years, the traditional means of distance education universities have to expand enrollment, student trying to reduce costs and improve efficiency. But with the development of online education, more and more school principal was no longer traditional university patents, many well-known large companies started to engage in virtual forms of training of higher education for the development of higher education in the form of structure has injected fresh vitality. Such as the University of Phoenix Online is now the largest of a network of educational institutions, the parent company of the Nasdaq Stock Exchange listed company, rather than a traditional university. 2001 
only, the Virtual University has more than 2 million students; Microsoft and other large companies under the auspices of MSCE skills certification training, skills certification it obtained knot lesson than some traditional university diploma more valuable. Without time and space limitations of computer network technology as the core to carry out a wide range of new distance learning, so that higher education is facing revolutionary changes, further exacerbating the conflict and competition in higher education.

\section{Conclusion}

Chinese higher education is facing a global international, market-oriented, information-based big impact, social development and changes in demand determine the structure of higher education must be adapted to reform the structure of higher education has become a necessity. Chinese market economy remains in a state of reform and development, the reform of higher education structures will also be a long and continuous process. Reform of higher education structures and has strong market adaptability, so we must adjust the structure of higher education institutions in accordance with the market environment and the specific conditions of the country to achieve the most optimized, so as to promote social and economic development. Structural problems of higher education directly influence and restrict the play and its own development and improving the quality of higher education functions, but also certain socio-economic, cultural and personnel structure is reflected in the higher education, it is to adapt to the development of socio-economic development and the continuous adjustment. Therefore, to develop higher education, and actively promote the reform of higher education, higher education is an important measure to achieve rapid and coordinated development, the country built Higher Education power.

\section{Acknowledgements}

Project Fund: Jilin Education Science "Thirteen Five" Plan 2016 Annual General Topic "Improvement of College Students' Innovative Entrepreneurship Practice Competence".

Project No.: GH16145.

\section{References}

[1] 198. UNESCO-APQN toolkit: regulating the quality of cross-boarder education. http: //www. unescobkk. org/elib/publications/087/APQN_Toolkit.pdf.

[2] Adam, Stephen. Multinational Universities and the Provision of Transnational Education in Europe. In M. Van Rooijen, David R. Jones and Stephen Adam. The Multinational University. EAIE Occasional Paper 15. Amsterdam, 2003: 43.

[3] APEC Symposium on Open Source and Open Course for E-leaming, Hanoi, Vietnam, 2006.

[4] Arum \& Van de Water. The Need for a Definition of International Education in U.S. Universities, [J]. In CB Klasek (Ed.) Bridges to the Future Carbondale: III. AIE App. 191-203.

[5] Banks, M. and G Mcbumie. Embarking on an Educational Journey-the Establishment of the First Foreign Full University Campus in Malaysia under the 1996 Education Acts: A Malaysian-Australian Case Study. Higher Education in Europe. Vol. XXIV, No. 2, 1999:265. 